RAD Conference Proceedings, vol. 4, pp. 69-71, 2020

ISSN 2466-4626 (online) | DOI: 10.21175/RadProc.2020.14

www.rad-proceedings.org

\title{
THE INFLUENCE OF SOLAR RADIATION AND FOREST FIRE SMOKE ON SPORADIC FLUCTUATIONS OF NEOPLASM INCIDENCE IN CHILDREN
}

\author{
S.K. Pinaev*
}

Far Eastern State Medical University, Khabarovsk, Russia

\begin{abstract}
We studied the dependence of cancer incidence in the young children ( 0 -4 years old) population of the Khabarovsk Territory (Russia) with the number of forest fires and solar radiation. It was established that the number of forest fires 2 years before the birth of children is associated with the incidence of Hodgkin's lymphoma, in the year of birth - with incidence of neuroblastoma and retinoblastoma. Fires that occurred 1 year after the birth of children had a linkage with the incidence of tumors of the central nervous system. The sunspot number 1 year before the birth of children was associated with non-Hodgkin's lymphomas, in the year of birth - with sarcomas of soft tissues, 3 years after birth - with a Wilms tumor. Leukemia incidence was found to be related both to the number of forest fires 2 years before the birth of children and to the sunspot number 3 years after their birth. For the combined group of embryonic tumors a significant link was found with the number of fires per year of birth, and the radiation of the Sun 1 year after the birth of children. Thus, fluctuations in the incidence of cancer in young children are associated with long-term changes over many years of the complex of environmental factors. We called this phenomenon "Alternative oncogenesis", implying a change in the incidence and spectrum of tumors over a certain period of time due to changes in the parameters of the complex of environmental factors.
\end{abstract}

Key words: Solar radiation, ecology, environmental factors, smoke, forest fires, prenatal, postnatal, children, carcinogenesis, childhood cancer, fluctuations of the incidence

\section{INTRODUCTION}

According to traditional notions, annual changes in the incidence rate of neoplasms are sporadic, random by nature. Therefore, to study the causes of tumors and to identify hidden trends, these fluctuations are aligned. We suggest an opposite thesis: fluctuations in the incidence of cancer have a causal character and are associated with environmental factors.

Out of the environmental factors, we chose solar radiation and smoke, because the role of ultraviolet light in the onset of malignancies is widely discussed, and the exposure to tobacco smoke in parents is a generally recognized risk factor for the development of tumors in children. In the Khabarovsk Territory (Russia), hundreds of forest fires occur every year, creating smoke that is staying for many months. In our opinion, the study of the influence of solar activity and smoke from forest fires on incidence of children neoplasms is of interest both for assessing the situation in the region and for gaining new knowledge about the causes of this pathology.

The objective was to summarize the main results of the papers of our group about the study of the influence of solar radiation and forest fires smoke on sporadic fluctuations of neoplasms incidence in children.

\section{MATERIALS AND METHODS}

A peculiarity of our approach is, first of all, a simultaneous study of the incidence of benign tumors and malignant neoplasms in young children $(0-4$ years old) within a single population, since tumor pathology at this age is predominantly of prenatal genesis. This allows getting the results in a fairly short time.

Were formed 11 cohorts of young children with benign tumors (693 cases) born at 1976-1986 and 17 cohorts with malignant neoplasms (138 cases) born at 1972-1988 in Khabarovsk town (Russia). The links of benign tumor incidence due the incidence of malignant neoplasms in cohorts was investigated by Pearson correlation [1].

To study the links between exposure to solar radiation and forest fires smoke with tumors a model of the ecosystem "Sun - Smoke of Forest Fire childhood neoplasms" was created. Were formed additionally 17 cohorts of young children with malignant neoplasms (572 cases) born at the all Khabarovsk Territory (Russia) in 1972-1988. The interrelation between the sunspot number, the quantity of forest fires, and the incidence of neoplasms in cohorts was investigated by pair Pearson correlation and multiple correlations [2] 


\section{RESULTS AND DiSCUSSION}

At the first stage of research we studied the relations between the incidence of benign tumors and malignant neoplasms in the young children cohorts. The presence of an inverse connection $(r=-0.705$; $\mathrm{p}=0.015$ ) was found between incidence rate of benign tumors, and of malignant neoplasms in the cohorts which were 1 year older [1]. This result obtained lead to two important conclusions.

First, the sporadic fluctuations in incidence of both benign tumors and malignant neoplasms in the young children population are not random. With a high probability, they are due to changes in the environmental factors complex, characterized by long multi-year cycles.

Second, oppositely directed changes in the incidence of benign tumors and malignant neoplasms under the influence of the same complex of factors indicate a fundamental difference in etiopathogenesis of these diseases. The discovered phenomenon is called by the authors "alternative oncogenesis". Under alternative oncogenesis, we mean predominant occurrence of either benign or malignant neoplasms due to a change in the parameters of the environmental factors complex at a certain period of time.

Obviously, the identified relation is not functional, due to the direct dependence of the incidence of benign tumors on the incidence of malignant neoplasms. Both of these variables depend on a set of common oncogenic factors for them, as a result of which the discovered patterns are formed. In other words, we did not find the cause of the occurring changes, but saw two interrelated consequences demonstrating at each separately taken time point the predominance of a benign or malignant scenario of oncogenesis in the young children population.

The main difference between malignant neoplasms and benign tumors is the ability of the former to metastasize due to the presence of a malignant phenotype, the important components of which are a decrease in intercellular adhesion, the ability to autocrine stimulation and perforin synthesis. One of the factors determining the formation of a benign or malignant phenotype of a neoplasm is the epigenomic activation of semaphorins $[3,4]$.

In the revealed phenomenon of alternative oncogenes much is unclear. We should answer several questions. How are all the varieties of environmental factors, their multiplicity and multidirectionality ultimately realized in the form of a single resultant vector affecting the process of tumor emergence? Why does oncogenesis in various initial tissues, having different etiology, under the influence of this vector pass through a certain point of dichotomy, after which either benign or malignant neoplasms predominantly develop? In our opinion, the most probable cause of alternative oncogenesis is natural environmental factors, since long-term cycles of activity are characteristic of biogenic, abiogenic, and cosmic influences. On the contrary, anthropotechnogenic impacts are usually not subject to significant annual fluctuations, with the exception of catastrophic events.
At the next stage of research we studied the dependence of benign tumors and cancer incidence in the young children population of the Khabarovsk Territory (Russia) on the exposure to solar radiation and forest fires smoke. The smoke of forest fires 2 years before the birth of children was associated with the incidence of lymphangiomas $(r=0.695 ; p=0.009)$, and for teratomas a connection with smoke was established 1 year before birth $(r=0.656 ; p=0.014)$ [2]. It was revealed that the number of forest fires 2 years before the birth of children was associated with the incidence of Hodgkin's lymphoma $(r=0.726$, $\mathrm{p}=0.001$ ) [2], in the year of birth - with incidence rate of neuroblastoma $(\mathrm{r}=0.736, \mathrm{p}=0.037)$ and retinoblastoma $(r=0.541, p=0.046)$ [5]. Fires that occurred 1 year after the birth of children were associated with the incidence of tumors of the central nervous system $(\mathrm{r}=0.533, \mathrm{p}=0.028)$ [2].

Studying the influence of the Sun, we detected a strong direct dependence between the sunspot number 3 years before the birth of children and the incidence of benign tumors $(r=0.785 ; \mathrm{p}=0.004)$ [2]. Several individual forms of benign tumors demonstrated a relation between the activity of the Sun 3 years before the birth of children and tumors of soft tissues ( $r=0.799 ; p=0.003$ ) [6], as well as papillomas of the skin and mucous membranes $(r=0.720 ; p=0.012)$ [2]. The sunspot number 1 year before the birth of children was associated with non-Hodgkin's lymphomas [2], in the year of birth - with sarcomas of soft tissues, 3 years after birth - with a Wilms tumor [5].

For hemangioma and leukemia, which are the most frequent forms of benign tumors and malignant neoplasms, respectively, a significant relationship was found with both the sunspot number and the smoke of forest fires. Multivariate analysis showed a strong multiple correlation between the activity of the Sun 3 years before the birth of children, the number of fires 3 years after their birth, and the incidence of hemangiomas $(\mathrm{R}=0.870 ; \mathrm{F}(2.8)=12.424 ; \mathrm{p}<0.004)$ [2]. Leukemia incidence was found out to be related to the number of forest fires 2 years before the birth of children and to the sunspot number 3 years after their birth $(\mathrm{R}=0.614, \mathrm{~F}(2.14)=4.236, \mathrm{p}<0.036)$ [5]. In the combined group of embryonic tumors a significant dependence was revealed between the number of fires per year of birth, and the activity of the Sun 1 year after the birth of children $(\mathrm{R}=0.912, \mathrm{~F}(2.5)=12.281$, $\mathrm{p}<0.012$ ) [5].

\section{CONCLUSION}

We believe that oxidative stress (OS) may serve as a vector that unites various environmental influences on a living organism during oncogenesis [8]. Moreover, if mutagenesis, as an element of oncogenesis, manifests itself as random mutations in single cells, then epigenesis is characterized by systemic processes covering the entire genome, and is highly influenced by OS. Therefore, although the literature describes the emergence of malignant neoplasms or benign tumors depending on the time of development of a mutation in a gene $[9,10]$, it seems to us that epigenesis due to 
ecologically caused OS, in comparison with mutagenesis, is a more likely candidate for the role of a "switch" in alternative oncogenesis.

In this regard, we see the direction of further study of alternative oncogenesis, first of all, in carrying out similar studies in extended time and territorial framework with an analysis of the connections between the environmental factors and individual nosological forms of benign tumors and malignant neoplasms. Mathematical modeling of the revealed features with the inclusion of the data on the accumulation of malignant neoplasms in the cohorts taken under observation throughout the subsequent adult life, as well as the findings on the dynamics and severity of environmental factors will help to clarify the role of specific pre- and postnatal environmental effects in the development of various forms of tumors.

Acknowledgements: The author would like to thank to Alexey Yaroslavovich Chizhov for valuable creative discussion, and to Nikolai Eduardovich Kosykh for help in collecting materials.

\section{REFERENCES}

1. S. K. Pinaev, O. G. Pinaeva, A. Ya. Chizhov, "Environmentally-induced alternative oncogenesis: EROS arrows", Actual Problems of Ecology and Environmental Management: Cooperation for Sustainable Development and Environmental Safety (APEEM 202O), E3S Web of Conferences 169, 04006, 2020 https://doi.org/10.1051/e3sconf/202016904006

2. S. K. Pinaev, O. G. Pinaeva, A. Ya. Chizhov, "About the role of environmental factors in carcinogenesis", Actual Problems of Ecology and Environmental Management: Cooperation for Sustainable Development and Environmental Safety (APEEM 2020), E3S Web of Conferences 169, 04003, 2020. https://doi.org/10.1051/e3sconf/202016904003

3. G. Neufeld, Y. Mumblat., T. Smolkin, S. Toledano, I. Nir-Zvi, K. Ziv, Kessler O., "The role of the semaphorins in cancer", Cell Adh. Migr., vol. 10, no. 6, pp. 652-674, 2016. https://doi.org/10.1016/i.drup.2016.08.001

4. D. Ito, S. Nojima, M. Nishide, T. Okuno, H. Takamatsu et al., "mTOR Complex Signaling through the SEMA4A-
Plexin B2 Axis Is Required for Optimal Activation and Differentiation of CD8+ T Cells", J. Immunol., vol. 195, no. 3, pp. 934-43, 2015. https://doi.org/10.4049/jimmunol.1403038

5. С. К. Пинаев, А.Я. Чижов, "Риск развития эмбриональных опухолей у детей в зависимости от радиации Солнца и дыма лесных пожаров", Радиация и риск, том 29, по.1, стр. 68-78, 2020. (S. K. Pinaev, A. Ya. Chizhov, "Impact of solar activity and the wildfire smoke on the risk of embryonal tumors in young children”, Radiation and Risk, vol. 29, no. 1, pp. 68-78, 2020).

https://doi.org/10.21870/0131-3878-2020-29-1-68-78

6. С. К. Пинаев, А. Я. Чижов, “Альтернативный онкогенез. "Системная динамика экологических факторов при новообразованиях у детей”, Успехи молекулярной онкологии, т. 5, по. 4, Приложение, стр. 18-19, 2018 (S. K. Pinaev, A. Ya. Chizhov, "Alternative oncogenesis. Systemic dynamics of environmental factors in neoplasms in children", $A d v$. Mol. Oncol. App., vol. 4, no. 5, pp. 18-19, 2018).

Retrieved from:

http://mol-oncol.com/project/moloncol.com/tezis all.pdf

7. А.Я. Чижов, С.К. Пинаев, “Системный анализ влияния солнечной радиации и дыма лесных пожаров на риск лейкоза у детей”, Радиация и риск, том 27, но. 4, pp. 87-94, 2018. (A. Ya. Chizhov, S. K. Pinaev, "Effects of solar radiation and woodsmoke on risk of childhood leukaemia: system analysis", Radiation and Risk, vol. 27, no. 4, pp. 87-94, 2018). https://doi.org/10.21870/0131-3878-2018-27-4-87-94

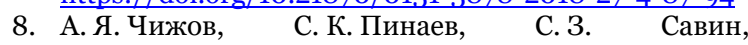
"Экологически обусловленный оксидативный стресс как фактор онкогенеза", Технологии живых систем, том 9, но. 1, стр. 47-53, 2012 (A.Ya. Chizhov, S.K. Pinaev, S. Z. Savin, "Environmentally-related oxidative stress as a carcinogenesis factor", Technologies of Living Systems, vol. 9, no. 1, pp. 47-53, 2012). https://www.elibrary.ru/item.asp?id=17741394

9. J. Vitte, F. Gao, G. Coppola, A. R. Judkins, M. Giovannini, "Timing of Smarcb1 and Nf2 inactivation determines schwannoma versus rhabdoid tumor development”, Nat. Commun., vol. 8, no. 1, 2017. https://doi.org/10.1038/s41467-017-00346-5

10. A. Agaimy, W. D. Foulkes, "Hereditary SWI/SNF complex deficiency syndromes", Semin. Diagn. Pathol., vol. 35 , no. 3, pp. 193-198, 2018.

https://doi.org/10.1053/j.semdp.2018.01.002 